\title{
Kualitas Produk dan Harga Dalam Meningkatkan Minat Pembelian Konsumen Pada Rebana NS Di Kabupaten Gresik
}

\author{
Muchsin Zuhad Al'asqolaini (1) \\ Ahmad Junaidi Musthofa ${ }^{(2)}$ \\ Sekolah Tinggi Ilmu Ekonomi NU Trate Gresik ${ }^{(1)(2)}$ \\ muchsinzuhad@stienugresik.ac.id ${ }^{(1)}$ \\ zudgus80@gmail.com ${ }^{(2)}$
}

\begin{abstract}
The purpose of this study is to determine the effect of Product Quality and Price on Consumer Purchase Interests in Tambourine NS, and to analyze the effect partially and simultaneously of each variable, so that the data analysis method used is to use multiple linear regression analysis and hypothesis testing with test $t$ and $F$ test. In this study, the population was 35 regular customers of tambourine NS products using saturated samples. Data collection was carried out by giving a list of questions to respondents, namely regular customers tambourine NS. Based on the results of the analysis of multiple linear regression tests produce that Product Quality and Price Simultaneously influence 7.625 with a significance of 0.000. While the partial test results of Product Quality partially influence 4,322 with a significance of 0,000 results. another case with Prices which partially does not affect the Consumer Purchase Interest. The most dominant variable in influencing consumer purchase interest is product quality.
\end{abstract}

Keywords: Product Quality; Price; Consumer Purchase Interests

\begin{abstract}
ABSTRAK
Tujuan dari Penelitian ini adalah untuk mengetahui pengaruh Kualitas Produk dan Harga terhadap Minat Pembelian Konsumen pada Rebana NS, dan untuk menganalisis pengaruh secara parsial dan simultan dari setiap variabel, sehingga metode analisis data yang digunakan adalah dengan menggunakan analisis regresi liner berganda serta pengujian hipotesis dengan uji t dan uji F. Adapun dalam penelitian ini yang menjadi Populasi adalah pelanggan tetap produk rebana NS sebanyak 35 orang dengan menggunakan sampel jenuh. Pengumpulan data dilakukan dengan cara memberikan daftar pertanyaan kepada responden yaitu pelanggan tetap rebana NS. Berdasarkan hasil analisis uji regresi linier berganda menghasilkan bahwa Kualitas Produk dan Harga berpengaruh secara Simultan sebesar 7,625 dengan signifikansi hasil sebesar 0.000. Sedangkan dari hasil uji parsial Kualitas Produk berpengaruh secara parsial sebesar 4.322 dengan signifikansi hasil sebesar 0.000. lain halnya dengan Harga yang secara parsial tidak berpengaruh terhadap Minat Pembelian Konsumen. Adapun Variabel yang paling dominan dalam mempengaruhi minat pembelian konsumen adalah Kualitas produk.
\end{abstract}

Kata kunci: Kualitas Produk; Harga; Minat Pembelian 


\section{PENDAHULUAN}

Kesenian merupakan hasil kebudayaan yang sudah sangat menyatu dengan kehidupan kita sehari-hari. Begitu juga dengan Kesenian Rebana merupakan salah satu kesenian yang telah tumbuh dan berkembang di Indonesia diperkirakan sejak abad ke 13 bersamaan dengan proses penyebaran agama Islam di Indonesia. Keberadaan kesenian rebana telah menjadi salah satu seni tradisi bagi masyarakat Indonesia khusunya di daerah Gresik. Sebagai salah satu kota santri, di Gresik kesenian musik dengan menggunakan rebana selalu mengiringi kegiatan diba'an, pernikahan, khitanan, halal bi halal, tasyakuran, perlombaan festival albanjari, hadroh dan peringatan hari besar Islam seperti Isro' Mi'roj Nabi, maulid nabi serta hari besar Islam lainnya.

Selain sebagai media hiburan, keberadaan kesenian rebana juga mempunyai fungsi utama untuk melakukan transformasi nilai budaya dan agama terhadap masyarakat, disamping itu juga untuk meningkatkan kecintaan kepada Allah SWT dan Nabi-Nya. para Wali Songo dahulu kala melakukan dakwah melalui kesenian berupa Wayang, syair, tembang Jawa. Adapun di era modern seperti sekarang ini kesenian musik rebana masih relevan untuk menjadi media yang sangat tepat guna memberikan peranan sebagai salah satu seni berdakwah dalam ikhtiar membangun karakter bangsa serta budi pekerti yang luhur. dari banyaknya penggunaan rebana di daerah Gresik, produk rebana yang beredar di pasaran juga sangat berpengaruh terhadap sikap seseorang ketika melakukan pembelian dan pemakaian suatu barang. pembeli mengawali proses pembelian ketika menyadari adanya masalah kebutuhan. Kadang-kadang Pembelian suatu produk atau barang tidak lagi untuk memenuhi kebutuhan, tetapi karena keinginan. Serta adanya konsumen yang memutuskan memilih memakai produk tertentu karena produknya sesuai dengan seleranya atau selera kelompoknya. konsumen memutuskan guna membeli suatu produk berdasarkan pada adanya minat pembelian.

(Bachriansyah, 2011) mengungkapkan bahwa: "Kualitas produk merupakan cerminan kekuatan produk untuk menjalankan tugasnya berupa daya tahan, kemajuan, kekuatan, kemudahan dalam pengemasan dan perbaikan produk dan ciri-ciri lainnya".

(Tjiptono, Chandra, \& Adriana, 2012) berpendapat bahwa: "Harga merupakan satusatunya unsur bauran pemasaran yang memberikan pendapatan bagi organisasi”.

Dari definisi diatas, dapat di simpulkan salah satu yang menjadi penentu keberhasilan perusahaan adalah harga karena harga menetukan seberapa besar keuntungan yang akan didapatkan oleh perusahaan dari hasil penjualan produknya. Adapun segmen pasar rebana yaitu semua golongan baik itu orang yang sudah tua, anak muda maupun anak kecil. Mereka ingin 
pada saat acara keislaman, penampilanya bisa memuaskan dirinya dan orang lain. Sebagian besar pada saat festival al-banjari, banyak sekali saya jumpai rebana yang di gunakan peserta sangat bermacam macam. Kecenderungan ini membuat mereka menggunakan dan membeli produk rebana yang cocok. Begitu juga yang terjadi pada jam'iyyah rutinitas di musholla,masjid maupun yang lainnya. Seperti halnya pada saat lomba banjari di Gresik, salah satunya pada saat lomba banjari Se-Jawa Timur di Masjid Jami' Gresik, pengguna Rebana NS hanya dua grup sholawat saja yang memakainya Dari situlah dapat kita lihat bahwasanya produk rebana NS sangat minim penggunanya di bandingkan dengan produk - produk rebana yang lainnya seperti produk rebana Imam Bahri dari Bungah Gresik.

Produk rebana NS adalah salah salah satu kerajinan rebana yang berada di Desa Bungah Gresik, yang menjual berbagai rebana seperti rebana al-banjari / hadroh, rebana samroh, rebana habsyi dan rebana ishari. Dari Rebana yang dijual, kebanyakan konsumen membeli Rebana albanjari. Berdasarkan Uraian yang sudah dijelaskan di atas maka perlu dilakukan penelitian dengan judul: Pengaruh Kualitas Produk dan Harga terhadap minat pembelian konsumen pada rebana NS H.Imam Sanusi di Desa Bungah Kabupaten Gresik.

\section{Kualitas Produk}

Menurut (Oktaviani, 2014) yang dimaksud kualitas produk adalah: "sesuatu yang bisa ditawarkan ke dalam pasar untuk menjadi perhatian, mungkin untuk dimiliki, mungkin untuk dipakai, ataupun dikonsumsi sehingga dapat memuaskan keinginan atau kebutuhan”.

Kualitas biasanya berhubungan dengan manfaat atau kegunaan serta fungsi suatu produk (Oktaviani, 2014, Ginantra et al., 2017)

Menurut (Oktaviani, 2014) diantara beberapa atribut yang menyertai dan melengkapi produk adalah:

a. Brand/ Merek

Brand / Merek merupakan nama, istilah, tanda, simbol, atau rancangan, yaitu sebuah kombinasi dari semua yang dimaksudkan untuk identifikasi suatu produk maupun jasa dari satu atau dari kelompok penjual. Pemberian brand / merek merupakan hal yang utama dalam strategi menjual produk. disamping mahal serta memakan waktu, brand/ merek mampu menentukan suatu produk berhasil atau gagal.

b. Packing/ Kemasan

Packing/ Kemasan merupakan aktifitas untuk merancang, membuat tempat atau bungkus dari suatu produk. 
c. Product Quality / Kualitas Produk

Product Quality / Kualitas Produk adalah kehandalan suatu produk guna menjalankan fungsinya diantaranya: daya tahan kehandalan, ketepatan kemudahan operasi dan perbaikan, serta atribut lain yang bernilai.

Menurut (Oktaviani, 2014) "ketika merencanakan suatu penawaran produk, pemasar harus memahami lima tingkat produk, yaitu :

1. Care Benefit/ Produk Utama adalah manfaat yang benar-benar dibutuhkan serta akan dikonsumsi oleh pelanggan dari suatu produk.

2. Basic Produk/ Produk Generik adalah pemenuhan fungsi pokok produk yang paling mendasar.

3. Expected Product/ Produk Harapan merupakan suatu produk resmi yang penawarannya disertai berbagai atribut dan kondisi secara normal dengan harapan untuk dibeli.

4. Augment Product/ Produk Pelengkap yaitu bermacam- macam atribut produk yang dilengkapi dengan bermacam layanan dan manfaat yang mampu memberi nilai tambah kepuasan

5. Potential Product/ Produk Potensial, merupakan berbagai macam tambahan serta perubahan yang dimungkinkan untuk di kembangkan menjadi produk dimasa yang akan datang.

\section{Harga}

Menurut (Tjiptono et al., 2012) yang dimaksud Harga adalah: "satu-satunya unsur bauran pemasaran yang memberikan pendapatan bagi organisasi”. Harga adalah salah satu dari beberapa variabel penting dalam pemasaran, dimana harga dapat mempengaruhi konsumen dalam mengambil keputusan untuk melakukan pembelian suatu produk, karena berbagai alasan (Oktaviani, 2014)

Sedangkan menurut (Adyas, 2019) harga adalah: " jumlah uang yang telah disepakati oleh calon pembeli dan penjual untuk ditukar dengan barang atau jasa dalam transaksi bisnis normal".

\section{Peranan Harga}

Menurut (Tjiptono et al., 2012) : "peranan penting ekonomi makro, konsumen dan perusahaan diperankan oleh Harga".

Bagi perekonomian : harga suatu produk mempengaruhi tingkat gaji, harga sewa, kurs bunga dan laba. Harga adalah regulator dasar pada system perekonomian, harga mempengaruhi beberapa faktor produksi diantaranya, seperti: pegawai, modal, tanah, dan 
kemampuan berwirausaha. Tingkat upah yang tinggi menarik tenaga kerja, tingkat bunga yang tinggi menjadi daya tarik bagi investasi modal, dan seterusnya.

2. Tujuan ditetapkannya Harga

Program penetapan harga merupakan pilihan yang dijalankan oleh perusahaan terhadap harga umum yang berlaku relatif terhadap tingkat harga para pesaing. Penetapan harga mempunyai peran strategik yang penting dalam penerapan strategi pemasaran. (Adyas, 2019)

Harga yang ditetapkan oleh perusahaan mempunyai tujuan- tujuan tertentu, diantaranya: (1). fleksibelitas harga. (2). Tingkat harga terhadap kualitas produk. (3). kapan dan kepada siapa diskon dan bantuan itu akan diberikan. (4). Bagaimana biaya transportasi akan ditangani. (Adyas, 2019)

Dalam penetapan suatu harga, perusahaan perlu menjadikan pertimbangan berbagai macam aspek, di antaranya biaya. Dalam hal biaya perusahaan harus menghitung biaya tetap dan biaya variabel suatu produk (Adyas, 2019)

Faktor permintaan konsumen, Faktor pemerintahan mempunyai pengaruh terhadap penetapan harga, terlebih di Indonesia. Karena Pemerintah masih mempunyai hak untuk melindungi industri tertentu terkait dalam penetapan harga yang mana kebijakan ini dikenal dengan dumping yaitu menetapkan harga lebih murah untuk produk-produk yang dijual ke luar negeri. Faktor terakhir adalah kompetisi (persaingan) juga perlu dipertimbangkan dalam menentukan harga produk (Adyas, 2019)

diantara keputusan penting bagi perusahaan adalah penentuan harga. Salah satu prinsip bagi perusahaan dalam penentuan harga ini adalah menitik beratkan pada keinginan pembeli untuk harga yang sudah ditetapkan dengan jumlah yang cukup untuk menutup biaya dan mampu menghasilkan suatu laba, (Adyas, 2019).

\section{Minat Beli}

Menurut (Saidani \& Arifin, 2012) Minat beli adalah tahap kecenderungan responden untuk bertindak sebelum keputusan membeli benar-benar dilaksanakan. Terdapat perbedaan antara pembelian aktual dan minat pembelian ulang. Bila pembelian aktual adalah pembelian yang benar-benar dilakukan oleh konsumen, maka minat pembelian ulang adalah niat untuk melakukan pembelian kembali pada kesempatan mendatang.

Menurut (Kotler \& Keller, 2007) mengatakan bahwa aspek yang terdapat dalam minat beli antara lain :

a. Perhatian, adanya perhatian dari konsumen terhadap suatu produk. 
b. Ketertarikan, setelah perhatian maka akan timbul ketertarikan pada konsumen.

c. Keinginan, kemudian berlanjut kepada perasaan untuk memiliki produk tersebut.

d. Keyakinan, kemudian timbul keyakinan pada diri konsumen terhadap produk tersebut sehingga timbul keputusan untuk memper-olehnya dengan cara membeli produk tersebut.

e. Keputusan membeli.

f. Jika konsumen merasa puas maka akan timbul minat membeli ulang.

Minat beli konsumen itu dipengaruhi karena kualitas produk atau harga dan keduanya.

\section{Kerangka Konseptual}

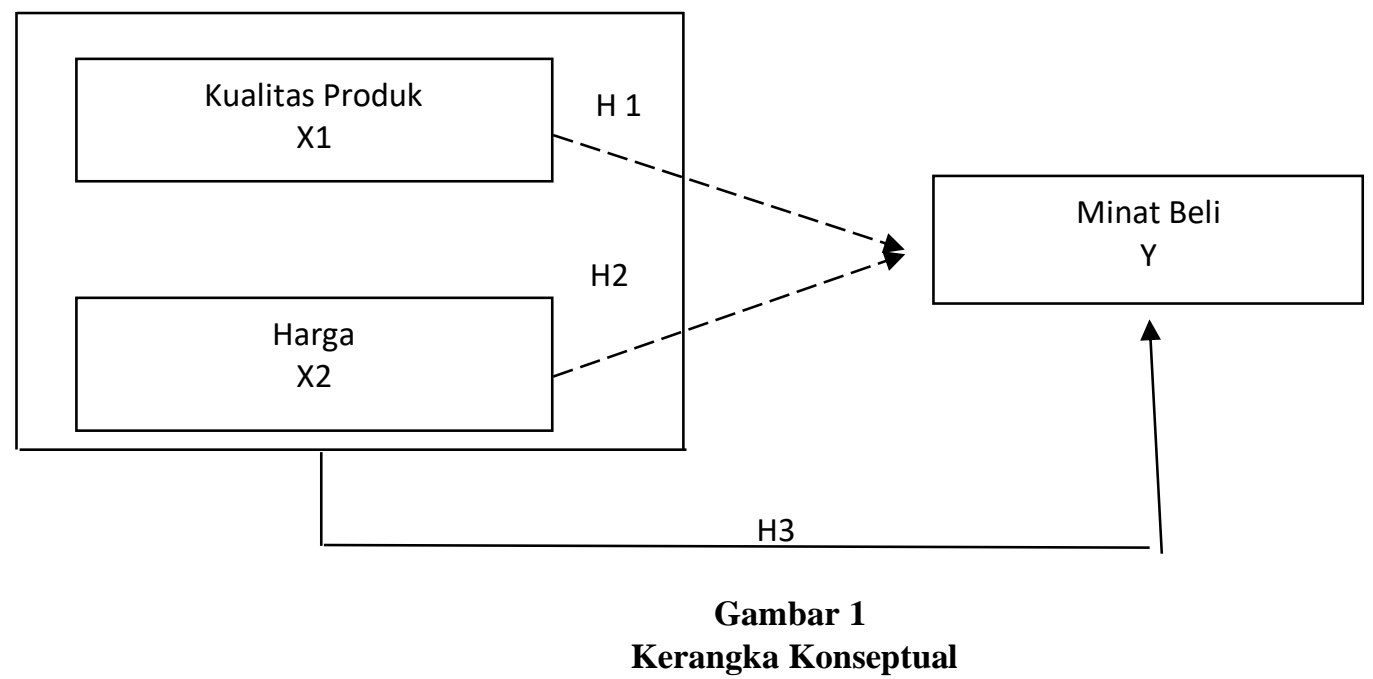

\section{METODE PENELITIAN \\ Desain Penelitian}

Jenis penelitian yang digunakan dalam Penelitian ini adalah penelitian eksplanatori dengan menggunakan pendekatan penelitian kuantitatif, Penelitian ini dilakukan pada konsumen tetap Rebana NS H. Imam Sanusi di Desa Bungah Kabupaten Gresik yang berjumlah 35 orang yang secara keseluruhan dijadikan sebagai sampel. Dalam penelitian ini peneliti menggunakan teknik sampling Non Probability Sampling atau sampel jenuh dimana sampel jenuh ini adalah menggunakan seluruh populasi sebagai sampel dimana jumlah sampel adalah dibawah 100 orang (Sugiono, 2016) Metode Pengambilan datanya adalah dengan penyebaran kuesioner. 


\section{Teknik Analisis Data}

Metode yang digunakan untuk menganalisa datanya adalah dengan menggunakan: (1) Uji Validitas (2) Uji Reliabilitas (3) Koefisien Determinasi (R2) dan (4) Analisis regresi linier berganda (5) Uji Hipotesis

\section{HASIL DAN PEMBAHASAN \\ Analisis Data}

\section{Uji Validitas}

Tabel 1

Uji Validitas

\begin{tabular}{|c|c|c|c|c|}
\hline No & Item & r table & r hitung & Keterangan \\
\hline 1 & Kualitas Produk & 0,2826 & 0,532 & Valid \\
& Indikator 1 & 0,2826 & 0,608 & Valid \\
& Indikator 2 & 0,2826 & 0,816 & Valid \\
& Indikator 3 & 0,2826 & 0,726 & Valid \\
& Indikator 4 & 0,2826 & 0,751 & Valid \\
& Harga & 0,2826 & 0,870 & Valid \\
& Indikator 1 & 0,2826 & 0,795 & Valid \\
& Indikator 2 & & & Valid \\
& Indikator 3 & 0,2826 & 0,534 & Valid \\
\hline 3 & Minat Beli & 0,2826 & 0,821 & Valid \\
& Indikator 1 & 0,2826 & 0,714 & 0,667 \\
& Indikator 2 & 0,2826 & & \\
& Indikator 3 & & & \\
& Indikator 4 & & & \\
\end{tabular}

Pada Tabel 1 Uji validitas semua instrument pada pertanyaan Kuisioner Penelitian ini dinyatakan valid.

\section{Uji Reliabilitas}

Tabel 2

Uji Reliabilitas

\begin{tabular}{|c|l|c|c|}
\hline No & \multicolumn{1}{|c|}{ Variabel } & Cronbach's Alpha & Keterangan \\
\hline 1 & Kualitas Produk & 0,606 & Reliabel \\
\hline 2 & Harga & 0,730 & Reliabel \\
\hline 3 & Minat Beli & 0,619 & Reliabel \\
\hline
\end{tabular}

Berdasarkan Tabel 2 Uji Reliabilitas menunjukkan bahwa semua instrument penelilitian reliable. Hal ini ditunjukkan dengan nilai Alpha Cronbach di atas atau sama 
dengan 0,6. Hasil uji reliabilitas variabel $\mathrm{X}_{1}$ (kualitas produk) sebesar 0,606, sedangkan nilai koefisien reliabilitas variabel $\mathrm{X}_{2}$ (harga) sebesar 0,730. Adapun nilai Koefisien reliabilitas variabel Y (Minat Beli) sebesar 0,619.

\section{Koefisien Determinasi (R2)}

Uji Koefisien Determinasi pada intinya adalah untuk mengukur seberapa jauh kemampuan model guna menjelaskan variasi variabel dependen (Bachriansyah, 2011) Koefisien Determinasi ini menggunakan Adjust $R$ Square karena lebih dapat dipercaya dalam mengevaluasi Model Regresi.

Tabel 3

Koefisien Determinasi (R2)

\begin{tabular}{|c|r|r|r|r|}
\hline & & & & \\
\hline Model & $\mathrm{R}$ & R Square & Adjusted R Square & Std. Error of the Estimate \\
\hline 1 & $.675^{\mathrm{a}}$ & .456 & .403 & .27829 \\
\hline
\end{tabular}

a. Predictors: (Constant), x2, x1

Pada Tabel 3 Koefisien Determinasi (R2) Hasil diketahui Nilai Adjust $R$ Square adalah 0,403 hal ini menunjukkan bahwa sebesar 40,3\% Minat beli Konsumen pada Rebana NS H.Imam Sanusi dipengaruhi oleh variasi dari kedua variabel dependen yaitu: Kualitas Produk dan Harga. Adapun sisanya sebanyak 59,7\% itu dikarenakan pengaruh variabel variabel selain dalam penelitian ini.

\section{Analisis Regresi Linier Berganda}

\section{Tabel 4}

\section{Coefficients ${ }^{\mathrm{a}}$}

\begin{tabular}{|c|c|c|c|c|c|c|}
\hline \multirow{2}{*}{\multicolumn{2}{|c|}{ Model }} & \multicolumn{2}{|c|}{$\begin{array}{c}\text { Unstandardized } \\
\text { Coefficients }\end{array}$} & \multirow{2}{*}{$\begin{array}{c}\begin{array}{c}\text { Standardized } \\
\text { Coefficients }\end{array} \\
\text { Beta } \\
\end{array}$} & \multirow[b]{2}{*}{$\mathrm{t}$} & \multirow[b]{2}{*}{ Sig. } \\
\hline & & B & Std. Error & & & \\
\hline \multirow[t]{3}{*}{1} & (Constant) & 1.315 & .691 & & 1.901 & .067 \\
\hline & kualitas_produk & .624 & .144 & .604 & 4.322 & .000 \\
\hline & Harga & -.156 & .150 & -.150 & -1.042 & .305 \\
\hline
\end{tabular}

a. Dependent Variable: minat_beli

\section{Regresi Linier Berganda}

Sumber: Output SPSS 
Dari tabel 4: Regresi Linier Berganda diketahui hasil secara keseluruhan dan dapat di interpretasikan sebagai berikut:

$$
\begin{aligned}
& Y=a+b 1 X_{1}+b 2 X_{2}+e \\
& Y=1,315+0,624 X_{1}-0,156 X_{2}+e
\end{aligned}
$$

Hasil persamaan regresi linier berganda menunjukkan bahwa :

a. Konstant sebesar 1.315 jika Variabel Kualitas Produk ( $\left.\mathrm{X}_{1}\right)$ dan Harga $\left(\mathrm{X}_{2}\right)$ bernilai Nol maka nilai Variabel Minat Beli Konsumen (Y) Nilainya sebesar 1,315.

b. Koefisien regresi kualitas Produk $\left(\mathrm{X}_{1}\right)$ diperoleh sebesar 0.624 dan menunjukkan hubungan yang searah, Nilai 0.624 menunjukkan apabila variabel kualitas produk $\left(\mathrm{X}_{\mathbf{1}}\right)$ naik sebesar 62,4\% maka minat beli Konsumen (Y) akan naik sebesar 62,4\% dengan asumsi variabel lain tidak berubah dalam hal ini Kualitas Produk $\left(\mathrm{X}_{\mathbf{1}}\right)$ berkorelasi secara positif terhadap minat beli konsumen $(\mathrm{Y})$

c. .Koefisien regresi Harga $\left(\mathrm{X}_{2}\right)$ diperoleh sebesar -0.156 dan menunjukkan hubungan yang berlawanan arah, Nilai 15,6\% menunjukkan apabila variabel Harga $\left(\mathrm{X}_{2}\right)$ naik sebesar 15,6\% maka minat beli Konsumen (Y) akan naik sebesar 15,6\% dengan asumsi variabel lain tidak berubah dalam hal ini Harga $\left(\mathrm{X}_{2}\right)$ berkorelasi Negatif terhadap minat beli konsumen $(\mathrm{Y})$.

\section{Uji Hipotesis}

\section{a. Uji Parsial (Uji t)}

Tabel 5

\section{Uji Parsial (Uji t)}

Coefficients $^{\mathrm{a}}$

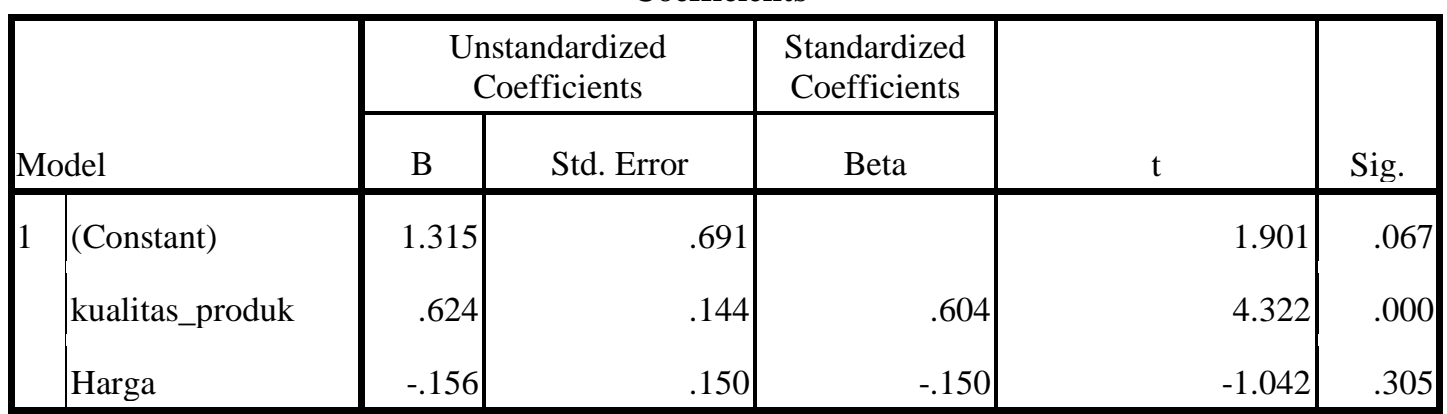

a. Dependent Variable: minat_beli

Sumber: Output SPSS 
Sebagaimana tabel 5 diatas adalah merupakan hasil penghitungan Uji Parsial (Uji t), Uji hipotesis dilaksanakan dengan membandingkan t-hitung dan t-tabel dengan tingkat kepercayaan sebesar $5 \%=(0,05)$, jumlah data $(\mathrm{n})$ yang valid adalah sebanyak 35 , jumlah variabel $(\mathrm{k})$ adalah $2 \mathrm{dan} \mathrm{df}=\mathrm{nk}-1$. Sehingga nilai $\mathrm{df}=32$, diperoleh dengan $\mathrm{t}$-tabel sebesar 1.69389

\section{b. Uji Simultan (Uji F)}

Penggunaan Uji F adalah untuk menguji signifikansi pengaruh variabel bebas secara simultan terhadap variabel terikat. Untuk menguji hipotesis adalah sebagai berikut:

H_0 : Tidak ada pengaruh yang signifikan, Kualitas Produk (X1), dan Harga (X2) secara simultan pada Minat Pembelian Konsumen (Y).

H_1 : Ada pengaruh yang signifikan, Kualitas Produk (X1), dan Harga (X2) secara simultan pada Minat Pembelian Konsumen (Y).

Jika angka $\mathrm{F}$ hitung > Tabel $\mathrm{F}$ maka $\mathrm{H} \_0$ ditolak.

Dan jika angka F hitung < Tabel F maka H_0 diterima.

Tabel 6

Uji Simultan (Uji F)

ANOVA $^{\mathrm{b}}$

\begin{tabular}{|c|c|c|c|c|c|c|}
\hline \multicolumn{2}{|c|}{ Model } & Sum of Squares & Df & Mean Square & $\mathrm{F}$ & Sig. \\
\hline 1 & Regression & 2.010 & 2 & .670 & 7.625 & .000 \\
\hline & Residual & 2.401 & 32 & .077 & & \\
\hline & Total & 4.411 & 35 & & & \\
\hline
\end{tabular}

a. Predictors: (Constant), x2, x1

b. Dependent Variable: $y$

Dari tabel 6 dapat dilihat bahwa hasil dari nilai F hitung adalah sebesar 7,625 sementara F tabel sebesar 3,29. Sementara nilai sig yang diperoleh adalah sebesar 0,000 dan nilai $a=5 \%$ atau 0,05 . Hal Ini menunjukkan bahwa $F$ hitung lebih besar dibandingkan $F$ tabel, maka H_0 ditolak dan H_1 diterima artinya ada pengaruh secara simultan dan signifikan antara variabel bebas $(\mathrm{X})$ yaitu Kualitas Produk dan Harga terhadap variabel terikat (Y) yaitu Minat Beli Konsumen. 


\section{PEMBAHASAN}

Dari hasil pengujian hipotesis uji t menjelaskan bahwa variable kualitas produk (X1) sebesar 4.322 dengan signifikansi hasil sebesar 0.000. pengujian ini membuktikan bahwa ada pengaruh secara parsial antara variabel Kualitas Produk (X1) terhadap Variabel Minat Beli Konsumen (Y). hasil penelitian ini sejalan dengan penelitian terdahulu yang telah dilakukan oleh (Isnaini, 2015) yang berjudul Pengaruh Kualitas Produk dan Harga terhadap Minat Beli Smartphone di kalangan mahasiswa pada Jurusan Akuntansi Universitas Muhammadiyah Surakarta Angkatan 2013 yang menjelaskan bahwa Kualitas Produk berpengaruh secara Parsial terhadap minat beli smartphone. Yang mana dari hasil Uji t tersebut maka $\mathrm{H}_{-} 1$ diterima.

Selanjutnya dari hasil pengujian hipotesis dengan menggunakan uji t menjelaskan bahwa variabel Harga sebesar -1.042 dengan signifikansi hasil sebesar 0.305. dimana pengujian ini membuktikan bahwa tidak ada pengaruh secara parsial antara variabel Harga terhadap Variabel Minat Beli Konsumen (Y). hasil ini tidak sejalan atau berbeda dengan penelitian terdahulu yang dilakukan oleh (Isnaini, 2015) yang menjelaskan bahwa Harga berpengaruh secara Parsial terhadap minat beli smartphone. Dengan hasil Uji t yang demikian ini maka H_1 ditolak.

Adapun hasil pengujian secara simultan dari Uji F menjelaskan bahwa telah diperoleh nilai F sebesar 7,625 dengan signifikansi hasil sebesar 0.000. Maka Pengujian ini membuktikan bahwa secara statistik Kualitas Produk dan Harga berpengaruh secara simultan terhadap Minat Beli Konsumen pada Rebana NS H.Imam Sanusi di Desa Bungah Kabupaten Gresik. hasil dari penelitian ini mendukung penelitian sebelumnya yang telah dilakukan oleh (Isnaini, 2015) dengan judul Pengaruh Kualitas Produk dan Harga terhadap Minat Beli Smartphone di kalangan mahasiswa Jurusan Akuntansi pada Universitas Muhammadiyah Surakarta Angkatan 2013 dimana pada penelitian tersebut Variabel Kualitas Produk dan Harga secara simultan memiliki pengaruh terhadap Minat beli.

\section{PENUTUP}

Sesuai dengan uraian diatas yaitu pada Hipotesis yang telah dirumuskan dan juga dari hasil uji hipotesis serta pembahasan yang telah ada didapatkan beberapa kesimpulan yaitu Kualitas Produk mempunyai pengaruh secara parsial terhadap minat pembelian konsumen, Sedangkan Harga tidak mempunyai pengaruh secara parsial terhadap minat pembelian konsumen, namun jika secara bersama - sama atau simultan kedua variabel bebas yakni Kualitas 
Produk (X1) dan harga (X2) mempunyai pengaruh terhadap variabel terikat yakni minat beli konsumen (Y). adapun variabel kualitas produk (X1) pengaruhnya dominan.

Dari hasil penelitian yang sudah ditemukan maka saran yang dapat diberikan Bagi Produsen, untuk supaya dapat mempertahankan, mengoptimalkan serta meningkatkan keunggulan yang dimilikinya tersebut, selalu memenuhi keinginan dan kebutuhan konsumen melalui kritik atau saran serta berusaha untuk berinovasi lagi dalam desain dan produk. Terkait Harga untuk mencapai laba maksimum produsen bisa meningkatkan penetapan harga yang agak lebih tinggi dari sebelumnya tetapi dengan catatan kualitas produk tetap dijaga terlebih ditingkatkan. Bagi penelitian selanjutnya, agar memperluas jangkauan penelitian dengan menambah sampel serta variabel lain yang belum ada pada penelitian ini. 


\section{DAFTAR PUSTAKA}

Adyas, D., dan I. S. (2019). Pengaruh Kualitas Produk, Harga dan Citra Merek Terhadap Keputusan Pembelian Sepeda Motor Honda CBR150R di Cibinong, 10: 29. Fakultas Ekonomika dan Bisnis.

Bachriansyah, R.A. (2011). Analisis Pengaruh Kualitas Produk, Daya Tarik Iklan, dan Persepsi Harga Terhadap Minat Beli Konsumen Pada Produk Ponsel Nokia ( Studi Kasus Pada Masyarakat di Kota Semarang ). Faculty of Economics and Business, Department of Management, 9-65. Retrieved from http://eprints.undip.ac.id/27924/

Ginantra, K.G., Lestari, N.P.N.E., Gorda, A.A.N.E.S., and Darma, G.S. (2017). Effects of Promotion, Product Quality, Brand Image and Price on Customer Satisfaction and Brand Switching Decision, International Journal of Management and Economics Invention, 3 (12): 1514-1523.

Isnaini, F. (2015). Pengaruh Kualitas Produk Dan Harga Terhadap Minat Beli Smartphone Di Kalangan Mahasiswa Jurusan Pendidikan Akuntansi Universitas Muhammadiyah Angkatan 2013. Universitas Muhammadiyah Surakarta.

Kotler, P., \& Keller, K. L. (2007). Manajemen pemasaran. edisi kedua belas jilid 1. Jakarta: PT. Indeks.

Oktaviani, L. (2014). Analisis Pengaruh Brand Image (Citra Merek), Kualitas Produk, dan Harga Terhadap Minat Beli Produk Mie Supermi (Studi Kasus Pada Konsumen Mie Instan Supermie di Kota Semarang), Diponegoro Journal of Management, 3 (1): 1-14.

Saidani, B., \& Arifin, S. (2012). Pengaruh kualitas produk dan kualitas layanan terhadap kepuasan konsumen dan minat beli pada ranch market, Jurnal Riset Manajemen Sains Indonesia, 3 (1): 1-22.

Sugiono, S. (2016). Metode Penelitian Kuantitatif, Kualitatif, dan $R \&$ D. Bandung: Alfabeta. Tjiptono, F., Chandra, G., \& Adriana, D. (2012). Pemasaran Strategik. Yogyakarta: Andi. 